\title{
Serum $25(\mathrm{OH})$ vitamin $D$ level and its relation to diabetic peripheral neuropathy in Egyptian patients with type 2 diabetes mellitus
}

\author{
Seham E. Abdelsadek ${ }^{1,4^{*}}$, Entesar O. El Saghier ${ }^{2,5}$ and Sabah I. Abdel Raheem ${ }^{3,5}$
}

\begin{abstract}
Background: Some clinical studies demonstrated a significant association between vitamin D deficiency and diabetic peripheral neuropathy (DPN).

Objective: This study aims to evaluate the correlation between serum levels of $25(\mathrm{OH})$ vitamin D and DPN in Egyptian patients with type 2 diabetes mellitus (T2DM).

Patients and method: Sixty patients were known to have T2DM, which classified into the following: group I included 40 patients with DPN and group II included 20 diabetic patients, without DPN, compared with 30 apparently healthy subjects of matched age and sex as control group. Laboratory investigations including fasting and 2-h postprandial blood glucose levels, serum calcium, phosphorus, glycosylated hemoglobin (HbA1c), lipid profile, serum $25(\mathrm{OH})$ vitamin $\mathrm{D}$, and nerve conduction studies were carried out for every participant to detect the existence and severity of DPN.

Results: Vitamin D deficiency was found in $73.3 \%$ of T2DM groups and in 35\% of control subjects with statistical significant differences $(p<0.005)$, and serum level of $25(\mathrm{OH})$ vitamin $\mathrm{D}$ in patients with DPN $(21.09 \pm 8.38)$ was less statistically significant than that in patients without DPN (31.12 \pm 14.85$)(p=0.001)$. Mean serum level of $25(\mathrm{OH})$ vitamin D in patients with painless DPN $(10.047 \pm 8.12)$ was less significant than that in patients with painful DPN $(18.14 \pm 3.85),(p<0.05)$. Regression analysis revealed that vitamin $D$ deficiency is one of the independent risk factors of DPN, (OD, 0.914), $(p=0.007)$.
\end{abstract}

Conclusion: Vitamin D deficiency has a significant role in the development and severity of DPN in Egyptian patients with T2DM.

Keywords: Type 2 diabetes mellitus, Diabetic peripheral neuropathy, 25(OH) vitamin D

\section{Introduction}

The most common cause of peripheral neuropathy in Egypt is diabetes mellitus (DM). Diabetic peripheral neuropathy is one of microvascular complications that causes morbidity and mortality in patients with diabetes mellitus; $50 \%$ of diabetic patients have diabetic neuropathy [1]. DPN complications are foot amputation due to painless

\footnotetext{
* Correspondence: Sehamelsaid121@gmail.com

${ }^{1}$ Neurology department, Faculty of Medicine for girls, AL-Azhar University, Cairo, Egypt

${ }^{4}$ Riyadh, Saudi Arabia

Full list of author information is available at the end of the article
}

foot ulcers, and diabetic autonomic neuropathy may be associated with life-threatening conditions such as sudden death and silent myocardial ischemia [2]. Vitamin D deficiency is a common public health problem all over the world [3]. Vitamin D deficiency contributes significantly to the pathogenesis of the two types of diabetes by impairing insulin secretion from pancreatic beta-cells [4] and increasing insulin resistance [5]. Clinical studies reported that vitamin $\mathrm{D}$ deficiency is more common in patients with diabetes and plays an important role in pathogenesis of diabetic neuropathies [6, 7]. Clinical observational studies demonstrated a significant association among patients 
with vitamin $\mathrm{D}$ deficiency, and neuropathic pain symptoms [8], neurological deficits, autonomic dysfunction [9], and electrophysiological studies in diabetic patients [10], Also, a prospective clinical study reported the improvement of neuropathic pain in DPN patients with vitamin D supplementation [11].

\section{Aim of the study}

To evaluate the correlation between serum levels of serum 25-hydroxyvitamin D and DPN in Egyptian patients with type $2 \mathrm{DM}$.

\section{Subjects and methods Study cohort}

A case control study was carried out during the period from October 2016 to March 2017 on 80 subjects: their ages ranged from 40 to 60 years. Sixty patients with T2 DM as patients group were selected from outpatient diabetes clinic and neurology clinic of Al-Zahra University Hospital, and the control group included 20 non diabetic healthy subjects of matched age and sex. They were selected from patient's relatives. Patients with T2DM had been classified into the following: group I: included 40 patients with DPN. DPN was diagnosed by clinical assessment (defined by presence at least two positive or negative sensory symptoms, signs, or reflex abnormalities) and abnormal results on nerve conduction studies (defined by the presence of at least one of amplitude, latency, F-wave, or nerve conduction velocity (NCV)) abnormalities in two or more nerves) [12]. Group II included 20 diabetic patients, without clinical evident DPN or abnormal nerve conduction studies. Inclusion criteria: all patients were known to haveT2DM, aged 40 to 60 years, duration of $\mathrm{DM} \geq 5$ years with glycated hemoglobin (HbA1c) level $\leq 10 \%$ at the screening visit. Exclusion criteria: patients with renal or liver disease, patients with infectious diseases or malignancies, subjects suffering from type $1 \mathrm{DM}$, patients with history of metabolic bone diseases, or hypothyroidism or hyperthyroidism, patients currently taking vitamin D supplementation, patients receiving medication that may alter vitamin $\mathrm{D}$ metabolism (antiepileptic, antituberculous, corticosteroids), patients with psychiatric disorder, and alcohol intake. Patients with peripheral neuropathy due to a non-diabetic cause and pregnant or breastfeeding female patients were excluded from the study.

\section{Ethical issues}

All subjects were informed of the general objectives of the study, and their participation in the study was fully voluntary. Confidentiality of collected data was guaranteed to participants, and an informed consent had been obtained. The study was approved by the Ethics Committee for Clinical Research of the Faculty of Medicine for Girls, Al-Azhar University.

\section{Methods}

All patients included in this study were subjected to full history taking, fundus examination, general and neurological assessment with special stress on the duration of diabetes, drug intake (insulin or oral hypoglycemic drugs), and the presence of subjective sensory symptoms such as pain, numbness, hypothesis, and their duration. Anthropometric measurements including weight, height, and body mass index (BMI) were calculated as weight in kilogram per height in meter, and waist circumference (WC) was measured with a tape midway between the costal margin and iliac crest in the mid-axillary line, while the subject is standing and breathing normally [13].

Assessment of peripheral neuropathy was done by neuropathy disability score (NDS) and nerve conduction studies. The NDS was established by bilateral examination of the pin-prick sensation, temperature sensation, vibration test, and Achilles tendon reflex. The sensory modalities were scored as either present $=0$ or absent/ reduced $=1$, whereas the scoring for the ankle jerks was as follows: present $=0$, present with reinforcement $=1$, absent $=2$, so the maximum abnormal score is 10 which indicates a complete loss of sensation to all sensory modalities and absent reflexes. A score of 0-2 implies no neuropathy, 3-5 is an indicator of mild neuropathy, 6-8 is moderate, and $9-10$ is consistent with severe neuropathy [14].

Patients with DPN were classified into painful and painless DPN patients according to McGill visual analog scale (VAS).VAS is a common research tool to assess the pain, it is formed of $10 \mathrm{~cm}$ a straight line which provides a continuous scale for subjective magnitude estimation, and the limits of this line represent the extreme of the symptoms, so in the McGill pain index assessment 0 represents no pain and 10 the worst pain ever [15].

Nerve conduction studies (NCS) were done for all subjects by using Cadwell Sierra Wave 8155 certified to CAN\TSA EP/EMG measuring system-4 channels-version 08.11, USA. The test was explained to the patients, and their consent to perform it was obtained. Proximal and distal latencies, amplitudes, and conduction velocities of both motor and sensory nerves were recorded. Motor NCS were studied for median, peroneal, and tibial nerves, and sensory nerve action potentials (SNAP) were measured from median, and sural sensory nerves also F-waves study for median nerves were done.

Laboratory investigations were done for patients and controls including complete blood picture. Liver function, kidney function, fasting and $2 \mathrm{~h}$ postprandial blood glucose levels, lipid profile including serum cholesterol, triglycerides (TG), high-density lipoprotein cholesterol (HDL-C) and low-density lipoprotein cholesterol (LDL-C) were examined after fasting $14 \mathrm{~h}$. Measurement of $25(\mathrm{OH})$ vitamin D serum levels were done by enzyme immunoassays using EDI. Total 25(OH) Vitamin D EIA 
Kit for the quantitative measurement of total serum 25-OH Vitamin D2/3 levels (Epitope Diagnostics, Inc., San Diego, CA, 92121, USA). Measurement of glycosylated hemoglobin (HbA1c) was done for patients group by quantitative calorimetric determination of glycolhemoglobin in whole blood kits supplied from Stanbio Laboratory, catalog number 0350 .

\section{Statistical analysis}

Data were analyzed using Statistical Package for Social Science (SPSS) version 20. Quantitative data were expressed using mean \pm standard deviation (SD) and ranges. Qualitative data were expressed as frequency and percentage. Independent samples $t$ test was used when comparing two independent groups regarding quantitative data with parametric distribution. Chisquare $\left(x^{2}\right)$ test was used to compare between two groups with qualitative data, Pearson's correlation coefficient $(r)$ test was used to describe the degree of correlation between two variables, and the sign of correlation coefficient $(+,-)$ defines the direction of the relationship either positive or negative. Receiver operating characteristic (ROC curve) analysis was used to find out the overall predictively of parameter in and to find out the best cut-off value with detection of sensitivity and specificity at this cut-off value. The probability and significance, $p$ value $<0.05$ was considered significant. $p$ value $<0.001$ was considered as highly significant. $p$ value $>0.05$ was considered insignificant.

\section{Results \\ Demographic and laboratory characteristics of studied groups}

This study has been carried out on 60 patients who were known to have T2 DM, (25 males and 35 females) with mean age $(46.87 .7 \pm 3.54)$ as patient groups which sub classified into the following: group I included 40 patients with DPN and group II included 2 diabetic patients, without DPN. Twenty healthy subjects (10 males and 10 females) with mean age (mean $46.35 \pm 2.25$ ) were used as control group. Mean serum levels of FBG, PPBG, total cholesterol, LDL, and BMI were significantly higher among T2DM patients group than control group $(p<0.001)$, but serum HDL and TG had no significant difference $(p>0.05)$. T2DM patients group had lower serum level of $25(\mathrm{OH})$ vitamin $\mathrm{D}$ than control group with no statistical significant difference $(p>0.05)$ (Table 1).

\section{Cut-off level of 25(OH) vitamin D deficiencies for T2DM groups and control group}

In the current study, receiver operating curve shows that cut-off level for vitamin D deficiency for T2DM groups

Table 1 Demographic and laboratory characteristics of T2DM groups (GI + GII) and control group

\begin{tabular}{|c|c|c|c|c|}
\hline \multirow[t]{2}{*}{ Group variables } & T2DM groups $(\mathrm{Gl}+\mathrm{GII}) N=60$ & Control group $N=20$ & \multirow{2}{*}{$\begin{array}{l}t \text { test/ } \\
x^{2}\end{array}$} & \multirow{2}{*}{$\begin{array}{l}p \\
\text { value }\end{array}$} \\
\hline & Mean \pm SD & Mean \pm SD & & \\
\hline Age (years) & $46.87 \pm 3.54$ & $46.35 \pm 2.25$ & 0.611 & 0.543 \\
\hline \multicolumn{5}{|l|}{ Sex } \\
\hline Females & $35(58.3 \%)$ & $10(50.0 \%)$ & \multirow[t]{2}{*}{0.423} & \multirow[t]{2}{*}{0.515} \\
\hline Males & $25(41.7 \%)$ & $10(50.0 \%)$ & & \\
\hline DM duration (years) & $8.58 \pm 5.39$ & - & - & - \\
\hline $\mathrm{BMI}\left(\mathrm{kg} / \mathrm{m}^{2}\right)$ & $31.49 \pm 4.01$ & $27.17 \pm 1.88$ & 4.627 & 0.000 \\
\hline W.C (cm) & $102.10 \pm 12.72$ & $83.80 \pm 7.14$ & 6.104 & 0.000 \\
\hline FBG (mg/dl) & $178.32 \pm 74.42$ & $84.23 \pm 9.00$ & 5.617 & 0.000 \\
\hline 2hpp (mg/dl) & $235.48 \pm 81.68$ & $106.85 \pm 9.62$ & 6.998 & 0.000 \\
\hline $\mathrm{CHO}(\mathrm{mg} / \mathrm{dl})$ & $206.23 \pm 58.66$ & $165.89 \pm 28.64$ & 2.952 & 0.004 \\
\hline $\mathrm{TG}(\mathrm{mg} / \mathrm{dl})$ & $164.69 \pm 87.29$ & $130.70 \pm 45.91$ & 1.662 & 0.101 \\
\hline $\mathrm{HDL}(\mathrm{mg} / \mathrm{dl})$ & $45.19 \pm 17.17$ & $45.74 \pm 11.01$ & -0.133 & 0.895 \\
\hline LDL (mg/dl) & $138.24 \pm 46.52$ & $105.79 \pm 26.73$ & 2.953 & 0.004 \\
\hline $\mathrm{Ca}(\mathrm{mg} / \mathrm{dl})$ & $9.43 \pm 0.46$ & $9.47 \pm 0.54$ & 0.311 & 0.757 \\
\hline $\mathrm{Ph}(\mathrm{mg} / \mathrm{dl})$ & $3.93 \pm 0.36$ & $3.69 \pm 0.51$ & -2.274 & 0.026 \\
\hline Creatinine (mg/dl) & $0.76 \pm 0.23$ & $0.89 \pm 0.21$ & 2.116 & 0.038 \\
\hline $25(\mathrm{OH})$ levels ng/ml & $24.43 \pm 11.84$ & $29.83 \pm 9.94$ & -1.832 & 0.071 \\
\hline
\end{tabular}

$D M$ diabetes mellitus, $B M I$ body mass index, WC waist circumference, $F B S$ fasting blood glucose, $2 h p p 2 \mathrm{~h}$ postprandial blood glucose, $C H O$ cholesterol, $T G$ triglycerides, $H D L$ high-density lipoprotein cholesterol, $L D L$ low-density lipoprotein cholesterol, $C a$ calcium, $P H$ phosphorus 
$(\mathrm{GI}+\mathrm{GII})$ and control group was $\leq 28.3 \mathrm{ng} / \mathrm{ml}$ with sensitivity of $87.5 \%$, specificity of $65 \%$, and accuracy of $75 \%$.

\section{Vitamin D status among T2DM groups and control group according to its cut-off level}

This study showed that $26.7 \%$ only of T2DM groups $(\mathrm{GI}+\mathrm{GII})$ had sufficient vitamin D $(25(\mathrm{OH})$ D > $28.3 \mathrm{ng} / \mathrm{ml}$ ), in comparison to $65 \%$ of control subjects $(p$ value 0.005$)$. Vitamin $\mathrm{D}$ deficiency $(25(\mathrm{OH}) \mathrm{D} \leq$ $28.3 \mathrm{ng} / \mathrm{ml}$ ) was detected in $73.3 \%$ of T2DM groups (GI + GII). While $35 \%$ only of control subjects being vitamin D deficient ( $p$ value 0.005 ).

\section{Demographic data, laboratory characteristics, and} neurophysiological studies of patient groups

As shown in Table 2, T2DM patients with DPN (group I) were older, had longer duration of DM, higher incidence of hypertension, poorer glycemic control (higher FBG, 2hpp, and HbA1c), and more impairment of neurophysiological studies than T2DM patients without DPN (group II).

\section{Vitamin D status amongT2DM group I with DPN and group II without DPN}

In the current study, the mean serum level of $25(\mathrm{OH})$ vitamin D in patients with DPN (group I) (21.09 \pm 8.38) was highly statistically significant lower than patients without DPN (group II) (31.12 \pm 14.85$)$ with $p$ value $=0.001$. Also, we found that $87.6 \%$ of patients with DPN had vitamin D deficiency $(25(\mathrm{OH}) \mathrm{D} \leq$ $28.3 \mathrm{ng} / \mathrm{ml}$ ) and $12.5 \%$ of them had sufficient serum level of vitamin D $(25(\mathrm{OH}) \mathrm{D}>28.3 \mathrm{ng} / \mathrm{ml}$ compared to patients without DPN. There were $55 \%$ with sufficient serum level of vitamin D and $45 \%$ had vitamin D deficiency $(25(\mathrm{OH}) \mathrm{D} \leq 28.3 \mathrm{ng} / \mathrm{ml}$ with statistical significant difference $(P=0.001)$.

\section{5(OH) vitamin D levels among patient with painful PDN} and patient with painless PDN

In the current study, T2DM patients with DPN divided into painful diabetic neuropathy patients $(n=18,45 \%)$ and painless diabetic peripheral neuropathy patients $(n=22,55 \%)$. There is statistically significant difference between patients

Table 2 Demographic data, laboratory characteristics, and neurophysiological studies of T2DM group I with DPN and group II without DPN

\begin{tabular}{|c|c|c|c|c|}
\hline Group variables & $\begin{array}{l}\text { T2DM group I } \\
\text { No }=40 \\
\text { Mean } \pm \text { SD }\end{array}$ & $\begin{array}{l}\text { T2DM group II } \\
\text { No }=20 \\
\text { Mean } \pm \text { SD }\end{array}$ & $t$ test $/ X^{2}$ & $p$ value \\
\hline Age (years) & $47.85 \pm 3.14$ & $44.90 \pm 3.54$ & 3.287 & 0.002 \\
\hline Sex & & & 0.857 & 0.355 \\
\hline Females & $25(62.5 \%)$ & $10(50.0 \%)$ & & \\
\hline Males & $15(37.5 \%)$ & $10(50.0 \%)$ & & \\
\hline DM duration (years) & $10.87 \pm 4.53$ & $4.02 \pm 3.88$ & 5.783 & 0.000 \\
\hline FBG $(\mathrm{mg} / \mathrm{dl})$ & $201.65 \pm 75.18$ & $131.65 \pm 46.46$ & 3.807 & 0.000 \\
\hline $2 \mathrm{hpp}(\mathrm{mg} / \mathrm{dl})$ & $264.38 \pm 81.11$ & $177.70 \pm 44.05$ & 4.450 & 0.000 \\
\hline $\mathrm{HbA} 1 \mathrm{c} \%$ & $8.31 \pm 1.45$ & $6.83 \pm 1.65$ & 3.541 & 0.001 \\
\hline Type of DPN & & & - & - \\
\hline Painless & $18(45 \%)$ & - & & \\
\hline Painful & $22(55 \%)$ & & & \\
\hline NDS & & - & & \\
\hline Mild & $12(30 \%)$ & & & \\
\hline Moderate & $7(17.5 \%)$ & & & \\
\hline Severe & $21(52 \%)$ & & & \\
\hline Median motor nerve cv $(\mathrm{m} / \mathrm{s})$ & $42.78 \pm 8.72$ & $59.05 \pm 5.12$ & -7.690 & 0.000 \\
\hline Median motor nerve amp (mv) & $3.75 \pm 1.61$ & $6.23 \pm 0.93$ & -6.350 & 0.000 \\
\hline Peroneal motor nerve cv & $31.85 \pm 4.68$ & $44.70 \pm 4.43$ & -10.200 & 0.000 \\
\hline Peroneal motor nerve amplitude & $1.30 \pm 0.40$ & $3.34 \pm 0.60$ & -15.60 & 0.000 \\
\hline Median sensory nerve cv & $31.68 \pm 5.20$ & $43.65 \pm 3.99$ & -9.046 & 0.000 \\
\hline Median sensory nerve amplitude (uv) & $9.42 \pm 4.940$ & $24.70 \pm 7.48$ & -9.470 & 0.000 \\
\hline Sural sensory nerve cv & $30.43 \pm 6.17$ & $42.50 \pm 2.82$ & -8.300 & 0.000 \\
\hline Sural sensory nerve amplitude & $1.07 \pm 0.42$ & $5.43 \pm 0.95$ & -24.647 & 0.000 \\
\hline
\end{tabular}

NDS neuropathy disability scale, $C V$ conduction velocity 
with painless and painful diabetic neuropathy as regard vitamin $\mathrm{D}$ deficiency, more affected in painless neuropathy. The mean serum level of $25(\mathrm{OH})$ vitamin $\mathrm{D}$ in patients with painless DPN $(10.047 \pm 8.12)$ was significantly lower than patients with painful DPN $(18.14 \pm 3.85),(p<0.05)$.

\section{Correlation of $25(\mathrm{OH}) \mathrm{D}$ level with the laboratory and neurophysiological studies in T2DM groups}

This study demonstrated that the serum level of $25(\mathrm{OH})$ vitamin $\mathrm{D}$ has statistically significant negative correlation with severity of DPN as regard to neuropathy disability scale (NDS) and neurophysiological studies (peroneal motor nerve amplitude, median sensory nerve amplitude, sural sensory nerve amplitude, and sural sensory nerve conduction velocity) ( $p$ value $<0.001$ ), also the serum level of D $25(\mathrm{OH})$ has a statistical significant positive correlation with serum calcium (Table 3).

\section{Vitamin D as independent risk factor for DPN in patients with type 2 diabetes}

Regression analysis test revealed that old age, long duration of DM, and high HbA1c were the most significant risk factors for development of DPN in T2DM patients. Also, the test revealed that vitamin D deficiency is one of these independent risk factors for DPN (OD, 0.914), $(p$ value $=0.007)$. $($ Table 4$)$.

\section{Discussion}

Egypt was listed as one of the world top 10 countries in the number of patients of diabetes. In 2013, International

Table 3 Correlation of $25(\mathrm{OH})$ D level with the laboratory and neurophysiological studies in T2DM groups

\begin{tabular}{|c|c|c|}
\hline \multirow[t]{2}{*}{ Variables } & \multicolumn{2}{|c|}{$25(\mathrm{OH}) \mathrm{D}$} \\
\hline & $r$ & $p$ value \\
\hline Age (years) & 0.030 & 0.856 \\
\hline DM duration (years) & 0.079 & 0.628 \\
\hline $\mathrm{BMI}\left(\mathrm{kg} / \mathrm{m}^{2}\right)$ & 0.113 & 0.487 \\
\hline W.C (cm) & -0.060 & 0.714 \\
\hline $\mathrm{Ca}(\mathrm{mg} / \mathrm{dl})$ & 0.286 & 0.027 \\
\hline $\mathrm{FBG}(\mathrm{mg} / \mathrm{dl})$ & -0.103 & 0.528 \\
\hline $2 \mathrm{hpp}(\mathrm{mg} / \mathrm{dl})$ & 0.009 & 0.956 \\
\hline NDS & -0.586 & 0.001 \\
\hline Median motor nerve $\mathrm{cv}(\mathrm{m} / \mathrm{s})$ & -0.189 & 0.242 \\
\hline Median motor nerve amp (mv) & -0.001 & 0.994 \\
\hline Peroneal motor nerve cv $(\mathrm{m} / \mathrm{s})$ & -0.216 & 0.180 \\
\hline Peroneal motor nerve amp (mv) & -0.495 & 0.001 \\
\hline Median sensory nerve $\mathrm{cv}(\mathrm{m} / \mathrm{s})$ & -0.151 & 0.027 \\
\hline Median sensory nerve amp (uv) & -0.286 & 0.249 \\
\hline Sural sensory nerve cv $(\mathrm{m} / \mathrm{s})$ & -0.387 & 0.004 \\
\hline Sural sensory nerve amp (uv) & -0.499 & 0.001 \\
\hline
\end{tabular}

Table 4 Regression analysis of risk factors for DPN in patients with type 2 diabetes

\begin{tabular}{lll}
\hline Univariate analysis & $p$ value & Odds ratio \\
\hline HbA1c \% & 0.000 & $9.333(2.576-33.823)$ \\
Age (years) & 0.001 & $1.975(1.263-3.089)$ \\
HTN (mmHg) & 0.003 & $1.396(1.183-1.647)$ \\
DM duration (years) & 0.004 & $1.276(1.080-1.507)$ \\
25(OH)D $(\mathrm{ng} / \mathrm{ml})$ & 0.007 & $0.914(0.856-0.976)$ \\
\hline
\end{tabular}

HTN hypertension

Diabetes Federation (IDF) estimated that 7.5 million individuals have diabetes and around 2.2 million have prediabetes in Egypt [16]. Accumulating data supposes that the prevalence of diabetes mellitus is increased with vitamin D deficiency [17]. Vitamin D deficiency increases the risk of developing T2DM and metabolic syndrome by causing pancreatic $\beta$ cell dysfunction and increasing the peripheral insulin resistance [18].

The clinical studies of the effects of vitamin D deficiency on Egyptian patients with T2DM and its role in diabetic neuropathy are rare.

This study was carried out to assess the serum levels of 25(OH) vitamin D in Egyptian patients with T2DM and the correlation between serum levels $25(\mathrm{OH})$ vitamin D and DPN.

Worldwide, vitamin D deficiency affects about one billion people [19]. Although the Middle East is sunny, people living in this region $\left(15^{\circ}\right.$ to $\left.36{ }^{\circ} \mathrm{N}\right)$ have high prevalence of vitamin D deficiency [20].

Some studies in the Middle East countries indicate that $70-80 \%$ of adolescent girls in Saudi Arabia and Iran had vitamin D levels of $<25 \mathrm{nmol} / \mathrm{L}$, while in Lebanon the figure was $32 \%$ in the same age group. Studies conducted among adults indicate a prevalence of $60-65 \%$ for vitamin $\mathrm{D}$ values $<25 \mathrm{nmol} / \mathrm{L}$ in Lebanon, Iran, and Jordan, and $48 \%$ for cut-off below $37.5 \mathrm{nmol} / \mathrm{L}$ in Tunisia [21].

The current study has been carried out in Cairo, Egypt located at $30^{\circ} 03^{\prime} \mathrm{N}$ and $31^{\circ} 14^{\prime} \mathrm{E}$; we found no statistical significant difference between T2DM groups and control group as regards to absolute serum level of $25(\mathrm{OH})$ vitamin D. We measured $25(\mathrm{OH}) \mathrm{D}$ levels in the summer season, which could have been the highest level. The time of year is an important factor in measuring vitamin $\mathrm{D}$ levels in the diagnosis of insufficiency or deficiency.

These results are in agreement with Usluogullari and colleagues [22] and Ahmadieh and colleagues [23]. However, Sarita and colleagues [24] found that serum 25(OH) D level was significantly lower in people with T2DM when compared to healthy subjects, which may be due to regional variability and susceptibility to vitamin D deficiency. 
In the current study, receiver operating curve demonstrate that cut-off level for vitamin $\mathrm{D}$ deficiency was $\leq$ $28.3 \mathrm{ng} / \mathrm{ml}$. Vitamin D deficiency $(25(\mathrm{OH}) \mathrm{D} \leq 28.3 \mathrm{ng} / \mathrm{ml})$ was found in $73.3 \%$ of T2DM groups and in $35 \%$ of control subjects with statistical significant difference.

The definition of vitamin D deficiency has been controversial, in part owing to the interpretation of surrogates associated with vitamin $\mathrm{D}$ status. Vitamin $\mathrm{D}$ deficiency has been historically defined and recently recommended by the Institute of Medicine (IOM) as a 25(OH)D below $20 \mathrm{ng} / \mathrm{ml}$, vitamin D insufficiency as a $25(\mathrm{OH}) \mathrm{D}$ of $21-29 \mathrm{ng} / \mathrm{ml}$, and sufficient vitamin D level as a $25(\mathrm{OH}) \mathrm{D}>30 \mathrm{ng} / \mathrm{ml}[25]$.

Consistent with the present research, the FIELD study has shown that vitamin D deficiency was present in 50\% of 9795 patients with type 2 diabetes, and it predicted microvascular complications [26].

Although some studies performed in sunny Middle East countries such as the study of Alhumaidi and colleagues [27], they have reported a high prevalence of vitamin D deficiency in Saudi Arabia (24 $\left.42^{\prime} \mathrm{N}, 46^{\circ} 43^{\prime} \mathrm{E}\right)$ among diabetics and non-diabetics individuals. Also, Haq and colleagues [28] and $\mathrm{Al}$ Anouti and colleagues studies

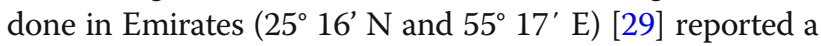
high prevalence of vitamin D deficiency among healthy Emirati adults. The same thing has been proved in Egypt by El Badawy and colleagues' study [30].

In the current study, the mean serum levels of $25(\mathrm{OH})$ vitamin D in patients with DPN were lower than that in patients without DPN. Also, we found that $87.6 \%$ of patients with DPN had vitamin D deficiency $(25(\mathrm{OH}) \mathrm{D} \leq$ $28.3 \mathrm{ng} / \mathrm{ml}$ ) compared to patients without DPN there were $45 \%$ had Vitamin D deficiency.

Diabetic patients are at high risk of micro vascular complications including DPN, which has bad impact on the quality of life, and it is associated with high mortality [31]. In Egypt, the prevalence of neuropathy ranged from $21.9 \%$ in hospital outpatient clinics to $60 \%$ in hospital inpatients [32].

The role of vitamin D in pathophysiology of DPN, some animal studies demonstrated the associations between vitamin D deficiency and low levels of nerve growth factors (neurotrophins) which are required for the development and survival of both sympathetic and sensory neurons, and cause defective neuronal calcium homeostasis [33]. Decrease in neurotrophins and defective calcium homeostasis increase nerve damage by toxins including hyperglycemia, also vitamin $\mathrm{D}$ receptor modulates neuronal cells differentiation and function. So, vitamin D deficiency impairs nociceptor function, worsens nerve damage, and lowers the pain threshold [34].

Clinical studies of Alamdari and colleagues [10], Bajaj and colleagues [24], and Putz and colleagues [35], reported a significant relation between vitamin $\mathrm{D}$ deficiency and diabetic neuropathy. Putz and colleagues [35] recommended vitamin $\mathrm{D}$ supplementation in patients with diabetic neuropathy.

Celikbilek and colleagues [36] examined the relation between serum vitamin $\mathrm{D}$, vitamin $\mathrm{D}$-binding protein (VDBP), and vitamin $\mathrm{D}$ receptor (VDR) with PDN; they found patients with DN had significant lower levels of vitamin $\mathrm{D}$ than that in patient without $\mathrm{DN}$, while there were similar values of VDBP and VDR in two groups of diabetic patients with and without DN.

In the present study, patients with DPN were divided into painful diabetic neuropathy patients $(n=18,45 \%)$ and painless diabetic peripheral neuropathy patients $(n$ $=22,55 \%$ ); the mean serum level of $25(\mathrm{OH})$ vitamin $\mathrm{D}$ in patients with painless DPN $(10.047 \pm 8.12)$ was significantly lower than that in patients with painful DPN $(18.14 \pm 3.85),(p<0.05)$. Also, the serum level of $25(\mathrm{OH})$ vitamin D has statistically significant negative correlation with severity of DPN as regards to NDS and nerve conduction studies ( $p$ value $<0.001)$.

Some clinical studies demonstrated significant relation between vitamin D deficiency [7] and severity of clinical manifestation of diabetic neuropathy (sensory, neurological deficits) and also with parameters of electrophysiology studies [8].

Alamdari and colleagues' study [10] found that the serum vitamin D level was significantly inversely correlated with the intensity of nerve conduction velocities impairment ( $p=0.001)$. Also, Kheyami's study [37] demonstrated that vitamin $\mathrm{D}$ receptor (VDR) expression is increased in diabetic neuropathy patients and the VDR up-regulation is associated with the severity of neuropathy and peroneal nerve conduction velocity, but there is no difference in VDR expression between painless neuropathy and painful neuropathy as demonstrated by this study. However, previous studies have suggested that vitamin D may act as an analgesic in painful diabetic neuropathy. The study done by Kheyami reported that vitamin D has analgesic effect in patients with painful DPN but vitamin $\mathrm{D}$ deficiency does not more associate with painful neuropathy than painless neuropathy [38].

To further examine the relationship between vitamin D and DPN, regression analysis test had been assessed. Long duration of DM, presence of hypertension, high HbAlc, and old age were the independent predictors of microvascular complications including DPN among T2DM. Besides these strong and well-known risk factors, vitamin D levels revealed a significant and independent association with DPN (OR 0.9, $p<0.007$ ). Zoppini and colleagues' study [39] found that higher serum $25(\mathrm{OH})$ D levels were independently associated with a reduced risk of prevalent microvascular complications. Also, clinical studies were done on patients with T2DM by Soderstrom and colleagues [8], Ahmadieh and 
colleagues [23], and Skalli and colleagues [40]. They concluded that vitamin D is an independent risk factor for development of DN. So, neuropathic pain can be relieved by replenish vitamin D deficiency, which reduces the use of medication for neuropathic pain like tricyclic antidepressant, antiepileptic, and narcotics with their often severe side effects. Also, the neuroprotective effects of vitamin D may reverse the neuronal damage and prevent the progression of DPN [6].

\section{Conclusion}

Until now, there is only symptomatic treatment for DPN with control of blood sugar. The present study with previous clinical studies demonstrated that vitamin D deficiency has a significant role and independent association with DPN, also vitamin D serum levels correlate with the severity of neuropathy in patient with T2DM; therefore, we recommend measurement of serum levels of $25-\mathrm{OH}$ vitamin $\mathrm{D}$ in all diabetic patients and vitamin $\mathrm{D}$ intake if there is vitamin D insufficiency.

\section{Abbreviation \\ BMI: Body mass index; DM: Diabetes mellitus; DPN: Diabetic peripheral neuropathy; EIA: Enzyme immunoassay; FBS: Fasting blood glucose; HbA1c: Glycosylated hemoglobin; HDL-C: High-density lipoprotein cholesterol; LDL-C: Low-density lipoprotein cholesterol; NCS: Nerve conduction studies; NCV: Nerve conduction velocity; NDS: Neuropathy disability score; PPBS: 2-h postprandial blood glucose; SNAP: Sensory nerve action potentials; TG: Triglycerides; VAS: McGill visual analog scale; VDBP: Vitamin D-binding protein; VDR: Vitamin D receptor; WC: Waist circumference}

\section{Acknowledgements}

Not applicable

\section{Funding}

No funding (self-funding).

\section{Availability of data and materials}

The datasets used and/or analyzed during the current study are available from the corresponding author on reasonable request.

\section{Authors' contributions}

SE carried out study designs and neurophysiological studies, participated in the sequence of alignment, and performed statistical analysis. EE participate in the study design and helped to draft the manuscript. SI carried out enzyme immunoassays and the laboratory investigations. All authors read and approved the final manuscript.

\section{Ethics approval and consent to participate}

The study was approved by the Ethics Committee for Clinical Research of the Faculty of Medicine for Girls, Al-Azhar University in December 2015, reference number not available.

All subjects were informed of the general aim of the study, and their participation in the study was fully voluntary. All participants provided informed written consent to participate in the study.

\section{Consent for publication}

Not applicable

\section{Competing interests}

The authors declare that they have no competing interests.

\section{Publisher's Note}

Springer Nature remains neutral with regard to jurisdictional claims in published maps and institutional affiliations.

\section{Author details}

${ }^{1}$ Neurology department, Faculty of Medicine for girls, AL-Azhar University, Cairo, Egypt. ${ }^{2}$ Endocrinology and Metabolism Department, Faculty of Medicine, AL-Azhar University, Cairo, Egypt. ${ }^{3}$ Clinical Pathology Department, Faculty of Medicine, AL-Azhar University, Cairo, Egypt. ${ }^{4}$ Riyadh, Saudi Arabia. ${ }^{5}$ Faculty of Medicine for Girls, AL-Azhar University, Cairo, Egypt.

Received: 4 January 2018 Accepted: 24 October 2018

Published online: 20 November 2018

\section{References}

1. Lv WS, Zhao WJ, Gong SL, Fang DD, Wang B, Fu ZJ, Yan SL, Wang YG. Serum 25-hydroxyvitamin $D$ levels and peripheral neuropathy in patients with type 2 diabetes: a systematic review and meta-analysis. J Endocrinol Invest. 2014. https://doi.org/10.1007/s40618-014-021.

2. Boulton AJM, Vinik Al, Arezzo JC, Bril V, Feldman EL, Freem R, et al. Diabetic neuropathies. Diabetes Care. 2005;28(4):956-62.

3. Hilger J, Friedel A, Herr R, Rausch T. A systematic review of vitamin D status in populations worldwide. Br J Nutr. 2014;111(1):23-45.

4. Reis AF, Hauache OM, Velho G. Vitamin D endocrine system and the genetic susceptibility to diabetes, obesity and vascular disease. A review of evidence. Diabetes Metab. 2005:31(4 Pt 1):318-25.

5. Knekt P, Laaksonen M, Mattila C, Harkanen T, Marniemi J, Heliovaara M, et al. Serum vitamin $D$ and subsequent occurrence of type 2 diabetes. Epidemiology. 2008;19(5):666-71.

6. Bell DSH. Reversal of the symptoms of diabetic neuropathy through correction of vitamin D deficiency in a type 1 diabetic patient. Case Rep Endocrinol. 2012;2012:165056 https://doi.org/10.1155/2012/165056.

7. Shehab D, Al-Jarallah K, Mojiminiyi OA, Al Mohamedy H, Abdella NA. Does vitamin $\mathrm{D}$ deficiency play a role in peripheral neuropathy in type 2 diabetes? Diabet Med. 2012;29:43-9.

8. Soderstrom LH, Johnson SP, Diaz VA, Mainous AG 3rd. Association between vitamin $\mathrm{D}$ and diabetic neuropathy in a nationally representative sample: results from 2001-2004 NHANES. Diabet Med. 2012;29:50-5.

9. Maser RE, Lenhard MJ, Pohlig RT. Vitamin D insufficiency is associated with reduced parasympathetic nerve fiber function in type 2 diabetes. EndocrPract. 2015;21:174-81. https://doi.org/10.4158/EP14332.

10. Alamdari A, Mozafari R, Tafakhori A, Faghihi-Kashani S, Hafezi-Nejad N, Sheikhbahaei $S$, et al. An inverse association between serum vitamin $D$ levels with the presence and severity of impaired nerve conduction velocity and large fiber peripheral neuropathy in diabetic subjects. Neurolsci. 2015; 36:1121-6.

11. Lee $P, C$ Chen $R$. Vitamin $D$ as an analgesic for patients with type 2 diabetes and neuropathic pain. Arch Intern Med. 2008;168(7):771-2.

12. Dyck PJ, Carter RE, Litchy WJ. Modeling nerve conduction criteria for diagnosis of diabetic polyneuropathy. Muscle Nerve. 2011;44(3):340-5. https://doi.org/10.1002/mus.22074.

13. Matsushita Y, Tomita K, Yokoyama T, Mizoue T. Optimal waist circumference measurement site for assessing the metabolic syndrome. Diabetes Care. 2009;32(6):e70.

14. Caselli A, Pham H, Giurini JM, Armstrong DG, Veves A. The forefoot-torearfoot plantar pressure ratio is increased in severe diabetic neuropathy and can predict foot ulceration. Diabetes Care. 2002;25(6):1066-71.

15. Burckhardt CS, Jones KD. Adult measures of pain: the McGill pain questionnaire (MPQ), rheumatoid arthritis pain scale (RAPS), short-form McGill pain questionnaire (SF-MPQ), verbal descriptive scale (VDS), visual analog scale (VAS), and west haven-Yale multidisciplinary pain inventory (WHYMPI). Arthritis Rheum. 2003;49:596-104.

16. Hegazi R, El-Gamal M, Abdel-Hady N, HamdyO. Epidemiology of and risk factors for type 2 diabetes in Egypt. Ann Glob Health. 2015;81(6):814-20.

17. Mezza T, Muscogiuri G, Sorice GP, Prioletta A, Salomone E, Pontecorvi A, et al. Vitamin $D$ deficiency: a new risk factor for type 2 diabetes. Ann NutrMetab. 2012;61(4):337-48.

18. Al-Daghri NM, Alkharfy KM, Al -Othman A, El-Kholie E, Moharram O, Alokail MS, et al. Vitamin D supplementation as an adjuvant therapy for patients with T2DM: an 18 -month prospective interventional study. CardiovascDiabetol. 2012;11(1):85. 
19. Holick MF. Vitamin D deficiency. N Engl J Med. 2007;357:266-81.

20. Alfawaz H, Tamim H, Alharbi S, Aljaser S, TamimiW. Vitamin D status among patients visiting a tertiary care center in Riyadh, Saudi Arabia: a retrospective review of 3475 cases. BMC Public Health. 2014;14:159. https://doi.org/10. 1186/1471-2458-14-159.

21. Mithal A, Wahl DA, Bonjour JP, Burckhardt P, Dawson-Hughes B, Eisman JA, et al. Global vitamin D status and determinants of hypovitaminosis D. Osteoporois Int. 2009;20:1807-20.

22. Usluogullari CA, Balkan F, Caner S, Ucler R, Kaya C, Ersoy R, et al. The relationship between microvascular complications and vitamin D deficiency in type 2 diabetes mellitus. BMC EndocrDisord. 2015;15:33. https://doi.org/ 10.1186/s12902-015-0029-y.

23. Ahmadieh H, Azar ST, Lakkis N, Arabi A. Hypovitaminosis D in patients with type 2 diabetes mellitus: a relation to disease control and complications. ISRNEndocrinol. 2013;2013:641098. https://doi.org/10.1155/2013/641098.

24. Bajaj S, Singh RP, Dwivedi NC, Singh K, Gupta A, Mathur M. Vitamin D levels and microvascular complications in type 2 diabetes. Indian J EndocrinolMetab. 2014;18(4):537-41. https://doi.org/10.4103/2230-8210.137512.

25. Holick MF, Binkley NC, Bischoff-Ferrari HA, Gordon CM, Hanley DA, Heaney RP, et al. Evaluation, treatment, and prevention of vitamin D deficiency: an Endocrine Society Clinical Practice guideline. J Clin Endocrinol Metab. 2011;96(7):1911-30.

26. Herrmann M, Sullivan DR, Veillard AS, McCorquodale T, Straub IR, Scott R, et al. FIELD study investigators. Serum 25-hydroxyvitamin D: a predictor of macrovascular and microvascular complications in patients with type 2 diabetes. Diabetes Care. 2015;38(3):521-8. https://doi.org/10.2337/dc14-0180 Epub 2014 Dec 18

27. Alhumaidi M, Agha A, Dewish M, Vitamin D. Deficiency in patients with type-2 diabetes mellitus in southern region of Saudi Arabia. MAEDICA - a. J Clin Med. 2013;8(3):231-6.

28. Al Anouti F, Thomas J, Abdel-Wareth L, Rajah J, Grant WB, Haq A. Vitamin D deficiency and sun avoidance among university students at Abu Dhabi, United Arab Emirates. Dermatoendocrinol. 2011;3(4):235-9.

29. Haq A, Svobodová J, Imran S, Stanford C, Razzaque MS. Vitamin D deficiency: a single Centre analysis of patients from 136 countries. J Steroid BiochemMol Biol. 2016;164:209-13. https://doi.org/10.1016/j.jsbmb.2016.02.007.

30. El Badawy AA, GFE S, Fahmy HH, Demitry SR, Sherif NA, Badawy SA E. Vitamin D status and some related factors among a sample of females living in rural area of Sharkia Governorate. Cairo: Egypt Osteoporosis Prevention Society Conference; 2009.

31. Raman R, Gupta A, Krishna S, Kulothungan V, Sharma T. Prevalence and risk factors for diabetic microvascular complications in newly diagnosed type II diabetes mellitus. SankaraNethralaya Diabetic Retinopathy Epidemiology and Molecular Genetic Study (SN-DREAMS, report 27). J Diabetes Complications. 2012;26(2):123-8. https://doi.org/10.1016/j.jdiacomp.2012.02.001.

32. Bos M, Agyemang C. Prevalence and complications of diabetes mellitus in Northern Africa, a systematic review. BMC Public Health. 2013;13:387.

33. Riaz S, Malcangio M, Miller M, Tomlinson DR. A vitamin D (3) derivative (CB1093) induces nerve growth factor and prevents neurotrophic deficits in streptozotocin-diabetic rats. Diabetologia. 1999:42(11):1308-13 [PubMed].

34. Mascarenhas R, Mobarhan S. Hypovitaminosis D-induced pain. Nutr Rev. 2004;62(9):354-9 [PubMed]

35. Putz Z, Martos T, Németh $N$, Körei AE, Szabó M, Vági O, et al. Vitamin D and neuropathy. Orv Hetil. 2013;154(51):2012-5.

36. Celikbilek A, Gocmen AY, Tanik N, Borekci E, Adam M, Celikbilek M. Decreased serum vitamin D levels are associated with diabetic peripheral neuropathy in a rural area of Turkey. ActaNeurol Belg. 2015;115(1):47-52 [PubMed].

37. Kheyami A. Vitamin D and Diabetic Neuropathy. A thesis submitted to the University of Manchester for the degree of MPhil in the Faculty of Medical and Human Sciences, vol. eScholarID; 2014. p. 227782.

38. Fukuoka M, Sakurai K, Ohta T, Kiyoki M, Katayama I. Tacalcitol, an active vitamin D3, induces nerve growth factor production in human epidermal keratinocytes. Skin PharmacolAppl Skin Physiol. 2001;14(4):226-33.

39. Zoppini G, Galletti A, Targher G, Brangani C, Pichiri P, Trombetta M, et al. Lower levels of 25-hydroxyvitamin D3 are associated with a higher prevalence of microvascular complications in patients with type 2 diabetes. BMJ Open Diabetes Res Care. 2015;3:e000058. https://doi.org/10.1136/ bmjdrc-2014-000058

40. Skalli S, Muller M, Pradines S, Halimi S. Wion-BarbotN.Vitamin D deficiency and peripheral diabetic neuropathy. Eur J Intern Med. 2012;23(2):e67-8. https://doi.org/10.1016/j.ejim.2011.11.008.

\section{Submit your manuscript to a SpringerOpen ${ }^{\circ}$ journal and benefit from:}

- Convenient online submission

- Rigorous peer review

- Open access: articles freely available online

- High visibility within the field

- Retaining the copyright to your article

Submit your next manuscript at $\boldsymbol{\nabla}$ springeropen.com 